Viewpoints

This article is based on a Presidential Lecture presented at the 2016 Annual Meeting.

\title{
The Puzzle of Visual Development: Behavior and Neural Limits
}

\author{
Lynne Kiorpes \\ Center for Neural Science, New York University, New York, New York 10003
}

The development of visual function takes place over many months or years in primate infants. Visual sensitivity is very poor near birth and improves over different times courses for different visual functions. The neural mechanisms that underlie these processes are not well understood despite many decades of research. The puzzle arises because research into the factors that limit visual function in infants has found surprisingly mature neural organization and adult-like receptive field properties in very young infants. The high degree of visual plasticity that has been documented during the sensitive period in young children and animals leaves the brain vulnerable to abnormal visual experience. Abnormal visual experience during the sensitive period can lead to amblyopia, a developmental disorder of vision affecting $\sim 3 \%$ of children. This review provides a historical perspective on research into visual development and the disorder amblyopia. The mismatch between the status of the primary visual cortex and visual behavior, both during visual development and in amblyopia, is discussed, and several potential resolutions are considered. It seems likely that extrastriate visual areas further along the visual pathways may set important limits on visual function and show greater vulnerability to abnormal visual experience. Analyses based on multiunit, population activity may provide useful representations of the information being fed forward from primary visual cortex to extrastriate processing areas and to the motor output.

Key words: amblyopia; visual cortex; visual development

\section{Introduction}

Investigations into the visual world of infants had their origins in the 1950s with a remarkable series of reports from Robert Fantz (1958) showing that infants' visual preferences can be measured and interpreted to reveal some basic perceptual abilities. Before, and in some sense despite, these reports, little attention was paid to infant visual function, infants were thought to be "blind" at birth, and little was known about the trajectory or time course over which vision became adult-like. This notion was apparently rooted in ophthalmology; a rendering of the process of visual development (in German, "Sehfunktion") starts from zero and proceeds toward adult levels over years (Fig. 1). The notion was widely accepted, and the original rendering was reproduced multiple times in the ophthalmology literature, although the origin is not known (Teller and Movshon, 1986; Levi, 2005). The drawing contains another critical point, however, the substance of which represents a driving principle for research in development over the subsequent $60+$ years, which is that as visual function ma-

Received Sept. 21, 2016; revised 0ct. 11, 2016; accepted 0ct. 12, 2016.

This work was supported by National Eye Institute R01 EY05864 and EY0217, the James S. McDonnell Foundation, Fight for Sight, New York University, National Institutes of Health/National Center for Research Resources 0D010425, and the Washington National Primate Center.

The authors declare no competing financial interests.

Correspondence should be addressed to Dr. Lynne Kiorpes, Center for Neural Science, 4 Washington Place, Room 809, New York University, New York, NY 10003. E-mail: Ik6@nyu.edu.

DOI:10.1523/JNEUROSCI.2937-16.2016

Copyright $\odot 2016$ the authors $\quad 0270-6474 / 16 / 3611384-10 \$ 15.00 / 0$ tures, developmental potential ("Entwicklungspotenz") declines, an early conceptualization of a sensory "critical period" reminiscent of the phenomenon of imprinting in Ethology (Hess, 1959). Konrad Lorenz is well known for having described a very early window in development within which experience determined the later behavior of the organism; in his case, posthatching experience determined attachment behavior in the greylag goose. These periods in vision are better thought of as sensitive periods, developmental intervals during which particular structures or functions are vulnerable to experience, or "plastic," rather than ones in which a particular kind of experience is required for the organism to survive.

The most stunning early demonstration of this phenomenon in mammalian visual system came with the work of Wiesel and Hubel (1963) in kittens. They reported a dramatic loss of representation of a deprived eye, characterized as a shift in ocular dominance away from a balanced binocular representation of the two eyes following the closure of one eye, in primary visual cortex when the deprivation occurred in the early postnatal weeks; there was no effect of the same deprivation in an adult cat. Subsequent work by Wiesel and Hubel and others carefully mapped the timing and duration of the sensitive period for ocular dominance in kitten striate cortex. Dramatic vulnerability of cortical binocularity to short periods of eye closure in kittens occurs soon after eye opening with a decline in vulnerability at older ages (e.g., Blakemore and Van Sluyters, 1974; Movshon, 1976a). Measure- 


\section{DIE ENTWICKLUNG DES SEHENS NACH DER GEBURT} THE POST-NATAL DEVELOPMENT OF VISUAL FUNCTION

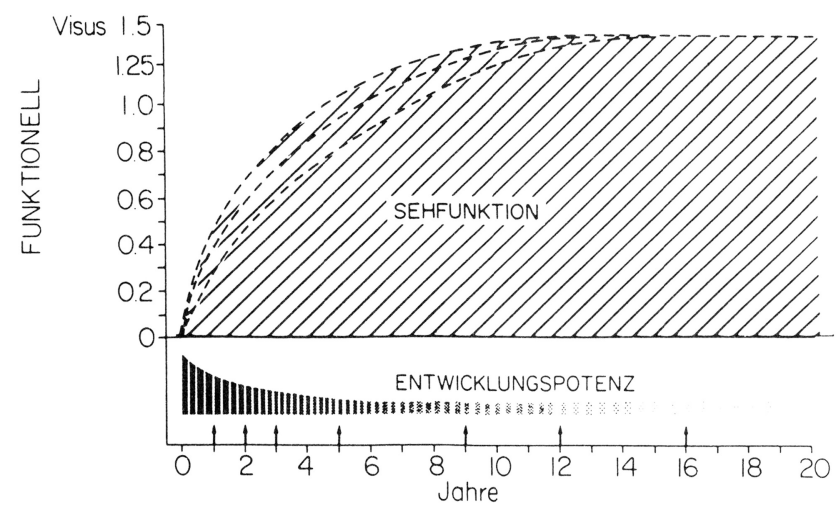

Figure 1. Drawing of the progress of visual development and the concurrent decline in "developmental potential." Adapted with permission from Teller and Movshon (1986), after Bangarter (1959).

ments extending earlier anecdotal observations of Wiesel and Hubel (1963) showed that animals deprived at young ages or for long periods of time behaved as though blind when required to use the deprived eye while minimal effects on vision resulted from interventions at later ages (Movshon, 1976b; Giffin and Mitchell, 1978; for review, see Movshon and Van Sluyters, 1981; Wiesel, 1982; Mitchell, 1991; Katz and Crowley, 2002). Reports, such as these suggesting a tight link between the effects of early postnatal visual experience and changes in neuronal properties and functional organization of primary visual cortex, spawned many lines of research into the mechanisms underlying cortical development and plasticity. This review will focus on two such directions: the neural limitations on normal postnatal visual development and the neural correlates of the developmental vision disorder, amblyopia, the most common cause of vision loss in children.

In this context, neural limitations are considered to be factors in the nervous system, be they anatomical or physiological, that are immature or disordered such that they set a gate on transmission of sensory information. An extreme example would be a set of neural elements at a particular juncture in the visual pathway, the maturation of which defined the developmental time course for all visual functions. This example represents a particular "linking hypothesis" (Teller, 1984), which is a framework for relating behavioral and neural phenomena. Several such hypotheses are considered below.

Since the early work on sensitive periods for vision in kittens, it has become clear that there are multiple visual sensitive periods and that different visual system structures and functions have different sensitive periods (for recent perspectives, see Daw, 1995, 1998; Levi, 2005; Kiorpes, 2015). For example, different visual functions, such as contrast sensitivity and spectral sensitivity, are differentially vulnerable to the effects of abnormal visual experience (Harwerth et al., 1990). These functions also develop along different time courses, which correlate with their sensitive periods. However, it is important to note that these time periods, normal development and the sensitive period, are not identical or synonymous (Daw, 1998).

Following the early studies of Hubel and Wiesel on the organization and neuronal response properties found in striate cortex of young cats and monkeys (Hubel and Wiesel, 1963; Hubel et al., 1977; Wiesel, 1982), there was effectively an explosion of research to define the rules that governed visual development, and the timing and degree of plasticity of species-typical organization (Movshon and Van Sluyters, 1981; Teller and Movshon, 1986; Crawford et al., 1989; Harwerth et al., 1989; Daw, 1995; Horton and Hocking, 1997). What has emerged from this large body of work is a picture of the infant visual brain, the organization of which is largely specified prenatally, based on a genetic plan, but which requires normal cell-cell interactions and activity patterns to be expressed (Rakic, 1977; Shatz, 1990; Goodman and Shatz, 1993; Katz and Crowley, 2002; Kennedy and Burkhalter, 2004; Espinosa and Stryker, 2012). The role of postnatal visual experience is to maintain and refine that existing organization (Wiesel, 1982; Movshon and Kiorpes, 1990; Hensch, 2004; Mitchell and Sengpiel, 2009). The initial assumption was that this postnatal reorganization and refinement permitted the development of visual function, not from zero, but from a baseline, low level of function to fully adult levels of vision. The puzzle to be solved is as follows: what is the relationship between postnatal neural maturation and the development of visual function?

In the midst of the intense research effort on the effects of visual deprivation in the late 1960s and early 1970s, a critically important and influential paper appeared by Horace Barlow on a framework for relating single neuron properties and subjective perceptual experience (Barlow, 1972). He defined a collection of five "dogmas" to serve as a basis for conceptualizing how neural activity translates visual stimuli in the real world to perception. A central principle of his proposal was that the activity of a small number of neurons with "trigger features" matched to important features of the environment through experience and developmental processes formed the basis for perception (Barlow, 1972). The challenge for those interested in visual development was to understand that matching process, that is, identify the appropriate linking hypothesis (Teller, 1984), as well as the cellular mechanisms of experience-dependent plasticity at a neural level. To approach that problem, it was necessary to define the state of the infant brain both functionally, as reflected in behavior, and mechanistically, by identifying the limits placed on infant vision via the functional organization and neural responsiveness of the visual pathways.

To make the comparison in the most direct way, it is necessary to use an animal model. For the purposes of this review, we focus on a nonhuman primate model, the macaque monkey, because it is the most appropriate model for human vision and visual development. The similarity between the visual system of human and old world nonhuman primates has been extensively documented (Boothe et al., 1985; Kaas, 2004; Van Essen, 2004). The spatial and temporal visual sensitivity of macaque monkeys in particular is very close to that of humans (De Valois et al., 1974a, b; Stavros and Kiorpes, 2008). For developmental models, it is critical for the developmental program to proceed similarly across species. Macaque monkey and human infants demonstrate parallel profiles for visual development from infancy to adulthood (Fig. 2) (Boothe et al., 1985; Kiorpes, 2008). Moreover, when studying a disorder, it is important that the behavioral and neural profiles of that disorder are similar between the model species and humans. Macaques naturally develop amblyopia (Kiorpes, 1989; Horton et al., 1997), and the approaches used to model human amblyopia in macaques yield a visual disorder that parallels the human condition both in basic visual function and more complex perceptual losses (Boothe et al., 1985; Kiorpes, 2008, 2015; Kiorpes and Mangal, 2015). 


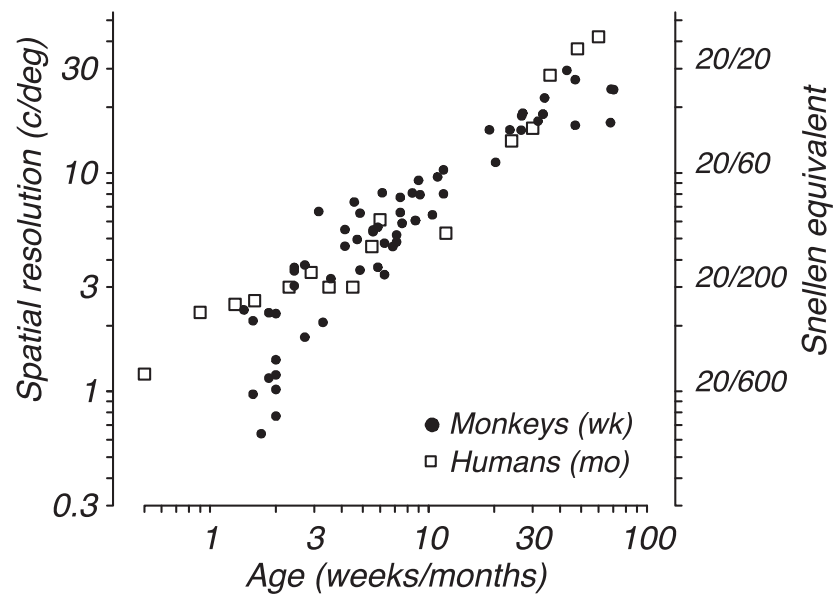

Figure 2. The development of spatial resolution in macaque monkeys and humans. Spatial resolution, or acuity, is measured via grating resolution with a combination of forced-choice preferential looking and operant testing methods for both species. The translation to Snellen acuity is represented on the right-hand ordinate. Age is plotted in weeks for macaques and months for humans. Both species show an increase in resolution on the order of a factor of 30 over the course of development. Monkey data are from Kiorpes (1992). Human data are from Mayer and Dobson (1982), redrawn from Kiorpes (2015).

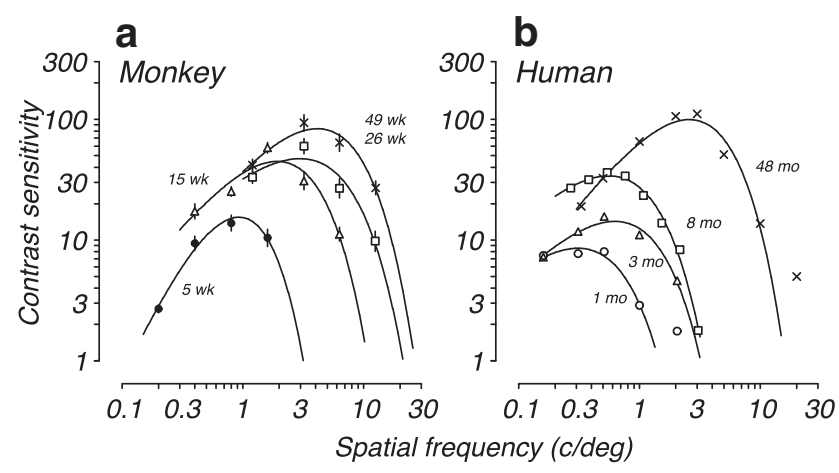

Figure 3. The development of contrast sensitivity in macaque monkeys and humans. Contrast sensitivity is plotted as a function of age for an individual macaque infant tested longitudinally $(\boldsymbol{a})$ and group data from multiple studies of human infants and children $(\boldsymbol{b})$. The pattern of improvement in contrast sensitivity with age is similar in the two species. The macaque data are from Boothe et al. (1988). The human data were compiled as average sensitivity at the spatial frequencies tested. The 1 and 3 month data are from Banks and Salapatek (1978). The 8 month data are from Peterzell et al. (1995). The 48 month data are from Ellemberg et al. (1999). Redrawn from Kiorpes (2008).

\section{What is the visual status of infant primates?}

The development of visual acuity and contrast sensitivity, basic measures of spatial visual ability, are shown in Figures 2 and 3 for humans and macaque monkeys. Spatial resolution, analogous to acuity measured with an eye chart, is plotted as a function of age for both species in Figure 2; example contrast sensitivity functions for a young monkey and group data from human infants are plotted in Figure 3. The plots show the closely parallel developmental trajectories for acuity and contrast sensitivity in macaques and humans. For acuity, the trajectories for the two species overlap completely when monkey age is plotted in weeks and human age is plotted in months; this comparison yields a simple scaling rule with monkeys developing $\sim 4$ times faster than humans (Teller and Boothe, 1979; Teller, 1997). Comparison of the human and monkey contrast sensitivity data follows the same rule. Figure 4 illustrates the effect of the poor spatial resolution and contrast sensitivity (and chromatic sensitivity) at age 1 week/ month. Figure 4 (left) is an unedited picture as would be seen through the eyes of a visually normal adult observer; the right panel shows the same image modified to simulate the view as seen by a very young infant. Clearly, the immature status of the infant visual system compromises its ability to faithfully represent the visual world. Additional properties of basic visual function, such as temporal vision, and motion perception are also measureable near birth but are immature; each develops over a unique time course that quite likely depends on the maturation of a related neural substrate (Fig. 5a-e) (Boothe et al., 1985; Teller, 1997; Kiorpes, 2008; Stavros and Kiorpes, 2008; Braddick and Atkinson, 2011; Kiorpes and Movshon, 2014).

There are, however, a number of visual functions, typically more sophisticated abilities or tasks requiring integration of information over space and/or time, that are not present at birth and only emerge at older ages. Examples of such abilities are stereopsis, figure-ground segregation, global form perception, and object recognition. The developmental trajectories for these functions are less well known, and there is much speculation regarding their neural substrates. Importantly, the developmental profiles for these visual functions are not directly correlated with the development of basic spatial vision. Figure 5 shows a direct comparison of acuity development with a variety of other visual functions. Higher-order visual functions (Fig. $5 f-h$ ) develop later and over longer time courses than basic visual functions. For example, Kiorpes and Bassin (2003) tracked the development of contour integration (a measure of figure-ground segregation) in infant macaques compared with acuity. Whereas acuity followed the typical time course, approaching adult levels $\sim 6$ months, the contour integration task was impossible for the same infants to perform before 5-6 months (Fig. 5h). Thus, the process of visual development is not uniform across different functions, and is perhaps hierarchical. Given the poor visual ability of infants, illustrated in Figure 4, which precludes parsing of objects, surfaces, and scenes, it makes sense that the development of these higher-order visual functions is delayed (Brown et al., 2007).

\section{Neural limits on visual development}

There are documented immaturities of both the eye and the retina of infant primates. For example, the eye grows, changing the image magnification, the optics and focusing ability of the infant change, the photoreceptors themselves grow and elongate, improving quantal absorption, and the high density of the cone photoreceptors typical of adult fovea develops postnatally over a somewhat prolonged trajectory. The greater process of retinal and photoreceptor maturation takes place over the first 6-8 months in macaque (Packer et al., 1990; Springer and Hendrickson, 2005) and 4-6 years in humans (Yuodelis and Hendrickson, 1986), whereas the other, optical changes take place early, before 3 months (Kiorpes et al., 2003; Kiorpes and Movshon, 2004). Are these changes sufficient to explain the developmental profile that is described behaviorally? This question can be addressed by using an ideal observer analysis (Geisler, 1984, 2004). An ideal observer takes account of the properties (anatomical, optical, physiological) at each step of the process of light capture, transduction, and output to the subsequent processing stages of the retina, and establishes what the best possible performance could be given those known properties of the system. The performance of the model is then compared with the performance of infants on a task, such as contrast detection, across age. Using this approach, it is clear that these front-end factors can affect the quality of the visual input to the brain in newborn macaques; but beyond about 


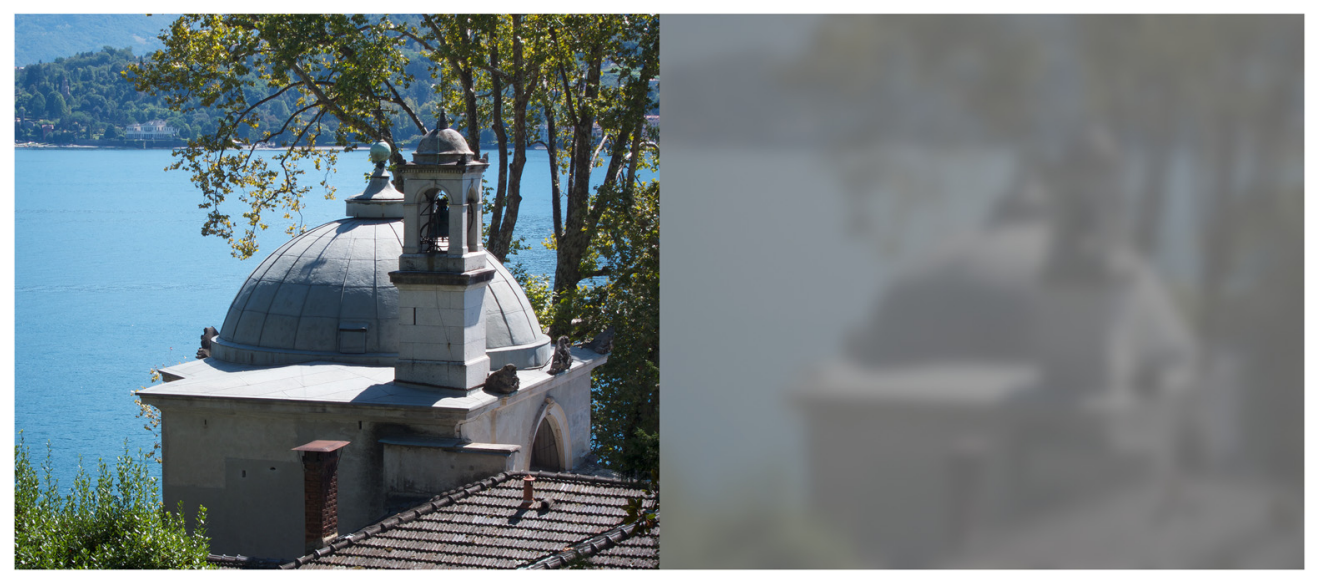

Figure 4. Illustration of the effect of the poor resolution and contrast sensitivity of the 1-week/month primate infant. Left, Lake-side picture, as viewed by a visually normal adult. Right, Same image filtered to represent the reduced spatial resolution (simulated by blur), and contrast and color sensitivity (simulated by contrast and saturation reduction) of the infant.

the first 4 weeks after birth, the sensitivity of the ideal observer model shows only moderate improvement and asymptotes at a level far superior to infant performance, whereas visual function continues to develop over many months. Thus, these peripherallevel changes cannot account for the subsequent development of vision (Kiorpes et al., 2003; Kiorpes and Movshon, 2004). Analyses of human infant vision support a similar conclusion (Banks and Bennett, 1988; Candy et al., 1998). These analyses establish that important limitations on infant visual development are not optical or photoreceptor-limited.

The neural computations related to visual activity in the retina are transmitted to the brain by the retinal ganglion cells, whose axons carry information to the lateral geniculate nucleus of the thalamus (LGN), among other subcortical sites. The geniculostriate pathway is the dominant route by which visual information from the periphery reaches the cortex in primates. Several investigations into the development of neural response properties at the level of the LGN have been conducted (Blakemore and VitalDurand, 1986a; Hawken et al., 1997; Movshon et al., 2005). All studies reported sluggish, long-latency responses from neurons in the youngest monkeys, but also evidence of typical receptive field organization. Movshon et al. (2005) recorded contrast responses and spatial and temporal resolution of LGN neurons in young macaques for comparison with behavioral development. They found improvement in all aspects of neural sensitivity on the order of a factor of 2-3 from 1 week of age to adult. However, the comparison with behavioral contrast sensitivity and acuity showed far superior neural sensitivity at the youngest ages and a rate of change much like that predicted by the ideal observer (Fig. 6 , squares, circles). Thus, the spatial properties of these neurons did not set an important limit on visual sensitivity. On the other hand, a comparison of behavioral and neural sensitivity to high temporal frequency modulation showed a very close match, suggesting that this aspect of visual development was indeed limited by neural sensitivity at or before the level of the LGN (Stavros and Kiorpes, 2008).

The early work on deprivation effects reviewed above led to the assumption that postnatal development, through reorganization and refinement, at the level of the primary visual cortex (V1), permitted the development of functional vision in infants. Early studies of the relative maturity of visual cortex focused on functional organization, mainly columnar organization related to binocularity and orientation, as well as other neuronal response properties (Hubel and Wiesel, 1963; Wiesel and Hubel 1974; Hubel et al., 1977;
Blakemore and Vital-Durand, 1981; Wiesel, 1982). The primary conclusions were that cortical neurons were weakly responsive and sluggish but that receptive field organization and structural organization in infants were similar to those in adults. Subsequent studies confirmed and extended these findings showing that, even in newborns and animals lacking visual experience, cortical organization was adult-like (Blasdel et al., 1995; Coogan and Van Essen, 1996; Horton and Hocking, 1996; Callaway, 1998; Batardiere et al., 2002; Kennedy and Burkhalter, 2004); physiological properties were comparatively mature as well (Chino et al., 1997; Kiorpes and Movshon, 2004a; Zhang et al., 2005, 2008, 2013; Zheng et al., 2007). Closer examination revealed that, whereas some receptive field properties, such as binocularity, orientation tuning, and direction selectivity, are fully mature at early ages, other aspects, such as neural acuity and contrast sensitivity, improved with age. However, as in the LGN, these properties improved on the order of a factor of 3 , and neural sensitivity was much better than expected based on the poor vision of infants (Fig. 6, triangles). These data call into question the assumption that maturation of $\mathrm{V} 1$ limits visual function in infants, defining its developmental time course. Indeed, what they show is that there is high-quality visual information represented in the infant brain that is not being used to guide behavior. These conclusions are supported by findings in human infants showing that visual evoked potential measures of visual sensitivity mature more rapidly than behavioral measures, reflecting the fact that the VEP is a summed signal from populations of visual cortical neurons (Norcia et al., 1990; Teller 1997).

In aggregate, the data provide a different perspective on the role of visual experience in brain development. The visual pathways up through area V1 are remarkably mature in infants, yet neural organization can be disrupted by visual experience. So the role of experience is not to shape the visual cortex per se, but instead to maintain it, and with the benefit of normal visual experience permit the maturation process to continue to completion. However, because the cortex remains plastic for some period of time after birth, the possibility for reorganization exists. It is important to note that, before V1, there is no significant physiological effect from even long-term monocular deprivation (Blakemore and Vital-Durand, 1986b; Levitt et al., 2001), revealing much reduced postnatal plasticity at this level. Monocular deprivation is indeed a very dramatic form of abnormal visual experience, which is beyond the realm of most common clinical conditions seen in humans. It is analogous to a very dense cataract appearing in the eye of an infant, allowing light perception 

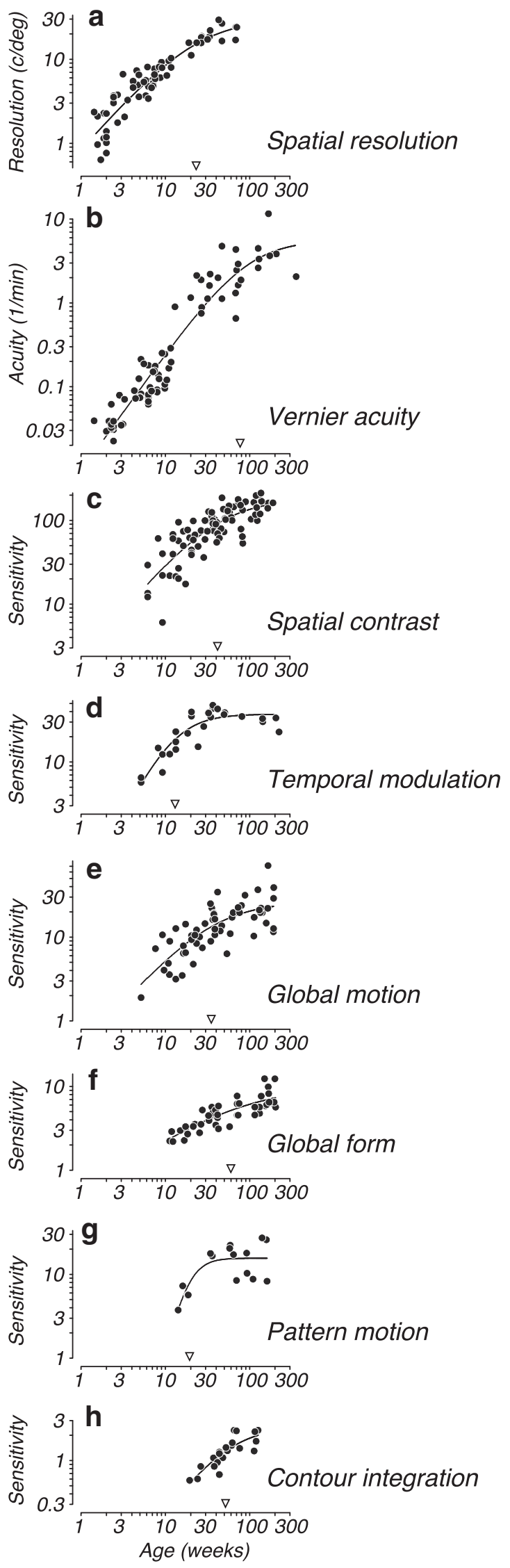

Figure 5. A comparison of developmental time courses for eight visual functions: a, Spatial resolution, as in Figure 2. b. Vernier acuity, a fine positional acuity that develops over a similar profile to spatial resolution but over a longer time course and improves on the order of a factor but not form vision. Happily, on the basis of the visual deprivation research done in cats and monkeys, clinical practice has now adopted the approach of removing cataracts from babies at very young ages, often as early as 6 weeks, so as to prevent the development of deprivation amblyopia (Birch and Stager, 1996; Lambert et al., 2001; Kiorpes, 2008; American Academy of Ophthalmology, 2015).

\section{Amblyopia}

Initially, monocular deprivation was promoted as a model for amblyopia. However, because of its devastating effects on vision and the cortex, other more appropriate models for human amblyopia have been developed. Amblyopia in children occurs most commonly in association with anisometropia (blur from unequal refraction in the two eyes) and strabismus (misalignment of the eyes), and typically results in more moderate degrees of vision loss than deprivation. These conditions can be modeled in monkeys by rearing them with artificial defocus, via lens-rearing or atropine drops, to simulate anisometropia, or artificial strabismus via surgical alteration of the horizontal eye muscles or prism-rearing (Smith et al., 1997; Kiorpes and Movshon, 2004; Kiorpes, 2008). These manipulations result in vision loss that is better matched to clinical experience (Fig. 7). Clinical standards for amblyopia are based on a difference in acuity between the eyes of 2 lines or more on an eye chart; the typical range of acuity difference is a factor of 2-4. Initial studies using these rearing conditions demonstrated that the abnormal visual experience was causal in the loss of visual function that followed the special rearing and the character of visual loss closely mirrored that seen in human amblyopia (von Noorden and Dowling, 1970; Kiorpes and Boothe, 1980; Harwerth et al., 1983; Kiorpes et al., 1987, 1989, 1992b).

Most research into the neural basis of amblyopia in nonhuman primates has been focused on area V1. One of the early studies directly compared behavioral, neurophysiological, and anatomical changes related to anisometropic rearing via atropine defocus in the same animals (Hendrickson et al., 1987; Kiorpes et al., 1987; Movshon et al., 1987). Anatomical and physiological changes were seen at the level of V1 but not earlier. Losses in behavioral acuity and contrast sensitivity were correlated with reductions in neural acuity and contrast sensitivity; however, the neural deficits were too small to account for the behavioral losses. This result is reminiscent of the findings in the normal infant brain, where neural function is more mature than behavioral function and information is present in the brain that appears to be unavailable to guide behavior. Furthermore, all animals showed a reduction in cortical binocularity, but they did not necessarily show an underrepresentation of the amblyopic eye in

$\leftarrow$

of $\sim 100$. c, Peak spatial contrast sensitivity. $\boldsymbol{d}$, Peak temporal modulation sensitivity. $\boldsymbol{e}$, Sensitivity to global motion measured with random dot kinematograms. $f$, Sensitivity to global form measured with Glass patterns. $\boldsymbol{g}$, Sensitivity to complex pattern motion measured with a plaid direction discrimination task. $\boldsymbol{h}$, Contour integration ability measured as a figurebackground discrimination. All eight visual functions illustrated here were measured using the same psychophysical task; the exact time course could be different depending on task and stimulus choice. The panels are ordered from top to bottom by age of onset of the visual ability. Smooth curves indicate Naka-Rushton functions illustrating the developmental profiles. Inverted triangles represent the age at which the function reaches one-half its asymptotic level, which is a metric for relative age at maturation. $\boldsymbol{a}, \boldsymbol{c}, \boldsymbol{d}$, Data are redrawn from Stavros and Kiorpes (2008). $\boldsymbol{b}$, Data are redrawn from Kiorpes (2015). $\boldsymbol{e}, \boldsymbol{f}$, Data are from Kiorpes et al. (2012). g, Data are from Hall-Haro and Kiorpes (2008). $\boldsymbol{h}$, Data are from Kiorpes and Bassin (2003). 


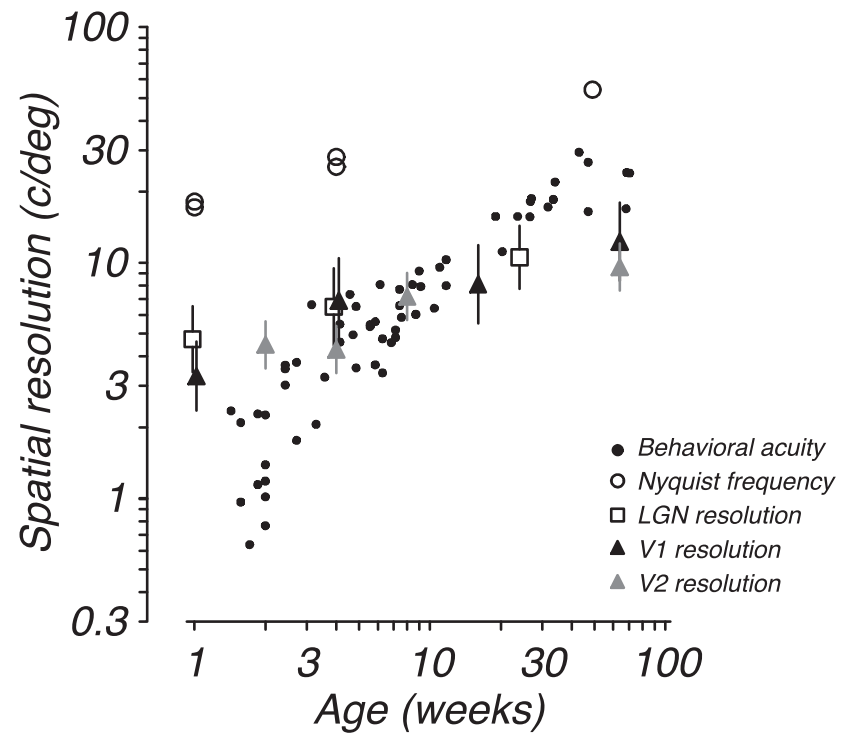

Figure 6. A comparison of behavioral and neural acuity development in macaque monkeys. Behavioral spatial resolution data are plotted as a function of age, as in Figure 2 (filled circles) along with neural measures of acuity: Nyquist frequency of the cone mosaic (open circles, data from Kiorpes et al., 2003), characteristic spatial frequency of parvocellular LGN neurons (open squares, data from Movshon et al., 2005), spatial resolution of V1 neurons (black triangles, data from Kiorpes and Movshon, 2004a), and spatial resolution of V2 neurons (gray triangles, data from Maruko et al., 2008). The overall extent of neural development is small compared with behavioral maturation. Redrawn from Kiorpes (2015).

cortex. Only those with the most severe amblyopia showed the shift in ocular dominance that characterizes monocular deprivation. Thus, the visual loss that accompanies amblyopia is not indeed a result of binocular imbalance alone (Wiesel, 1982; Kiorpes and Movshon, 2004). These findings were confirmed and extended by a subsequent study of neural correlates of amblyopia resulting from strabismus and anisometropia (Kiorpes et al., 1998). That study showed that ocular dominance was often balanced between the eyes despite the presence of amblyopia; this was especially true in cases of strabismic amblyopia. Smith and colleagues further showed that there are substantial residual binocular interactions among neurons in V1 and V2 of amblyopic monkeys (Smith et al., 1997; Bi et al., 2011).

Until recently, all investigations of the cortical correlates of amblyopia were based on single-cell recordings. A different approach was taken by Shooner et al. (2015), who performed a decoding analysis based on multielectrode array recordings in $\mathrm{V} 1$ and V2. They concluded that the difference in contrast sensitivity between the eyes, seen behaviorally, in amblyopes could be better captured by taking into consideration the response of the population of neurons dominated by (rather than driven by) each eye along with the reduction in sensitivity of those cells. This analysis suggested that the information that is read out from the early visual cortical areas can be characterized as a weak signal from the amblyopic eye resulting from a combination of poor neural sensitivity and reduced representation, depending on the depth of amblyopia. That weakness may be amplified as it traverses the visual pathways to the behavioral output.

Recent studies with amblyopic macaques have shown losses in higher-order and integrative visual functions that are qualitatively and quantitatively different from their losses in basic visual functions, such as acuity and contrast sensitivity (Kozma and Kiorpes, 2003; Kiorpes, 2006; Kiorpes et al., 2006; Nakatsuka et al., 2007; Wensveen et al., 2011; Kiorpes and Mangal, 2015).
These studies show amblyopic eye deficits, and sometimes dominant eye losses, in many functions related to parsing the visual world, such as contour integration, global form perception, and motion perception, which are the same visual abilities that develop late or have extended developmental time courses. It is unclear what neural mechanisms explain these more complex amblyopic perceptual losses, but they quite likely depend on abnormalities beyond V1. This profile may reflect a hierarchical cascade of development whereby late maturing visual abilities have extended sensitive periods, which leave them more vulnerable to abnormal visual experience.

Returning to Barlow's (1972) hypothesis regarding a small population of neurons with matched "trigger features," it seems that these neural features are very close to adult level at birth and change relatively little postnatally. The impact of abnormal visual experience on these features then is minimal. The most vulnerable synapses are those that receive converging input from the two eyes; studies in cat and mouse have shown that these synapses are modified during the sensitive period by typical Hebbian plasticity mechanisms as well as additional local synaptic and cellular processes (Daw, 1995; Hensch, 2004; Espinosa and Stryker, 2012; Coleman et al., 2013; Nagakura et al., 2014). Furthermore, the broad assumption (not made by Barlow) was that neurons with appropriate environmental trigger features lie in V1. Given the data reviewed above, three obvious alternatives can be proposed: (1) The specificity of a small number of single neurons determining perceptual experience is not the correct linking hypothesis. Perhaps a better conceptualization is one in which the collective output of V1, that is, the response of the population of V1 neurons, reflects perceptual experience. (2) There is a bottleneck, or "gate," somewhere along the pathway, for example, at or before the motor output, that must mature to permit the organism to fully express its perceptual experience. (3) There are "critical immaturities" (Teller, 1984) in visual areas further along the visual pathways that require an extended period of postnatal experience, a hierarchical model of development. To date, there are no developmental data available with which to assess the first hypothesis. However, the population analysis presented by Shooner et al. (2015) on the neural correlates of amblyopia suggests that this could be a promising approach. The second hypothesis seems unlikely given the diversity of developmental profiles seen for different visual functions. If there was a single bottleneck, the many visual functions studied would mature in concert. The idea of critical immaturities in downstream areas has appeal in particular because of the variety of developmental profiles. We now know that a great deal of visual processing takes place in extrastriate cortical areas comprising the dorsal and ventral visual streams (Bell et al., 2014). We can take advantage of the heterogeneity of developmental profiles to explore the possibility that those differential profiles reflect the maturation of higher-order visual areas.

There are only a few studies to date on the development of extrastriate visual areas in primates, with investigations into the development of areas V2, MT/V5, and inferotemporal cortex (Rodman et al., 1993; Distler et al., 1996; Zhang et al., 2013; for review, see Kiorpes and Movshon, 2014). Two particular experiments are relevant to the third hypothesis. First, Maruko et al. (2008) studied the development of disparity sensitivity in neurons in areas V1 and V2. O'Dell and Boothe (1997) had previously shown rapid development of stereopsis in infant monkeys, which is onset at $\sim 4$ weeks and matures by $\sim 10$ weeks. Maruko et al. (2008), aiming to identify the neural correlates of that rapid development, found that disparity sensitivity, which underlies 

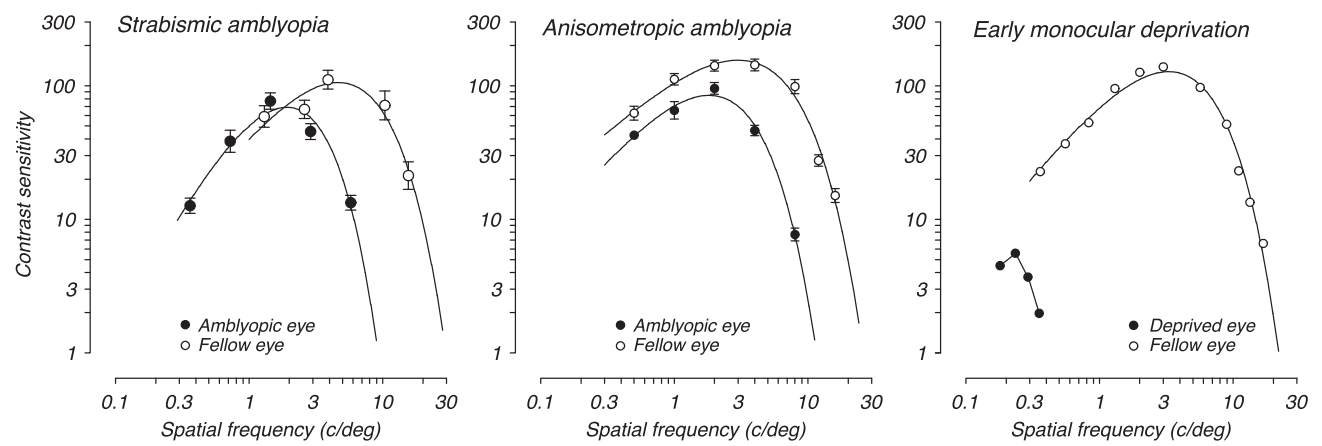

Figure 7. Characteristic amblyopic contrast sensitivity data from three macaque monkeys. Strabismic amblyopia (left) resulted from surgical alteration of the horizontal rectus muscles of one eye (data from Kiper and Kiorpes, 1994). Anisometropic amblyopia (middle) resulted from rearing with a defocusing lens over one eye (data from Kozma and Kiorpes, 2003). Deprivation amblyopia (right) resulted from rearing with one eye closed for 14 months (data from Harwerth et al., 1990). Redrawn from Kiorpes (2008).

stereopsis, was present as early as 2 weeks of age. However, the disparity properties of the neurons in combination with improved spatial resolution and responsiveness of V2 neurons over the first 8 weeks after birth could accurately model the behavioral development of stereopsis. Second, Movshon and colleagues studied the development of motion sensitivity in area MT (Kiorpes and Movshon, 2014), an area that in adults uniformly represents motion of objects and patterns (Movshon et al., 1985). The aim was to identify a substrate for the development of motion sensitivity, which is measureable near birth in infant monkeys but develops over a long time course (Fig. 5e) (Kiorpes and Movshon, 2004b). They found that even at 1 week postnatal, infant MT neurons showed adult-like signaling of direction of motion of objects (but not patterns); but like earlier areas of the visual pathways, infant responses were weak and long-latency. Simulating the population response of MT over the first 4 months after birth, they found a plausible match to the behaviorally measured developmental time course (Kiorpes and Movshon, 2014). Importantly, using a similar model, El-Shamayleh et al. (2010) were able to capture behavioral losses in motion perception that occur in amblyopic vision. Together, these findings suggest that maturation of downstream areas may indeed represent important limitations on development of visual function. They also suggest that population-level analyses provide a more accurate basis for linking neural activity and behavior than simpler comparisons of single-unit properties.

This review has focused on the macaque monkey as the model of choice for understanding visual development and amblyopia. However, it is important to acknowledge the substantial benefits of the cat as an animal model (Mitchell, 1989; Mitchell and Sengpiel, 2009). There is now a trend toward mouse models for investigations into mechanisms of visual system development, plasticity, and amblyopia. There are important differences between mice and higher species. The visual acuity of an adult mouse is an order of magnitude lower than that of a newborn human infant, the structure of the visual system at every level, beginning with the eye, is different from humans; and although there are areas of binocular overlap in the mouse visual cortex, the opportunity for binocular visual function, such as stereopsis, is extremely limited due to its laterally placed eyes. However, like cats and monkeys, mice show shifts in ocular dominance following closure of one eye as well as modest acuity loss in the deprived eye (Baroncelli et al., 2011; Bochner et al., 2014). But, as discussed above, amblyopia in primates can exist independently of ocular dominance shifts, and there is a broad constellation of deficits in higher-order visual func- tions for which there is no clear correlate in the mouse. In addition, visual deprivation is an extreme condition that is not necessarily representative of amblyopia more broadly. It is therefore important to be cautious about the parallels that can be drawn between the deprivation model in the mouse and human amblyopia. There is currently much work underway that is directed at understanding the genetic mechanisms that drive sensory system development, and the molecular and circuit-level modifications involved in cortical plasticity and recovery from deprivation for which the rodent is an important model system (Hensch, 2004; Mitchell and Sengpiel, 2009; Baroncelli et al., 2011; Espinosa and Stryker, 2012; Coleman et al., 2013; Bochner et al., 2014; Nagakura et al., 2014). It will be important to confirm critical findings in higher mammals, though, before extrapolating promising advances to humans.

\section{Conclusions and challenges for the future}

Research over the last 60 years has taken us from a notion of infants as blind and unresponsive to a wealth of knowledge about infant visual processing, the relevance of cortical development to the development of visual function, the importance of sensitive periods in postnatal sensory experience, and the value of normal binocular visual experience from an early age for the development of normal adult vision. We have seen that immaturities at the earliest levels of the visual pathway do not set important limits on the spatial vision of infants, although temporal resolution is limited early in the visual pathway, at or before the level of the LGN. Critical immaturities exist in extrastriate visual areas that may limit development as well as underlie losses in higher-order visual abilities in amblyopia. Amblyopia is a complex developmental visual disorder that can exist independently of a shift in ocular dominance, instead comprising a combination of neural sensitivity loss and imbalance in the representation of the amblyopic eye feeding forward in cortex. The challenge is to adequately capture the neural information that is being transmitted along the visual hierarchy, and to learn why the infant or amblyope is unable to fully access that information.

Linking hypotheses based on population representations rather than single cells can more accurately capture the processes involved in visual development and amblyopia. Similarly, analyses that attempt to link development of particular functions with extrastriate cortical development will undoubtedly provide important insights. The field could benefit from greater attention to linking hypotheses, generally. In the past, there has been much speculation about neural mechanisms underlying perceptual and 
cognitive phenomena, in adults and infants, without much attention to the nature of the implicit assumptions (Kiorpes et al., 2013; Welchman and Kourtzi, 2013). This issue is already being addressed more effectively in the context of amblyopia (Levi, 2013) and development (Atkinson and Braddick, 2013; Pallett and Dobkins, 2013), which will certainly enhance progress in these areas.

\section{References}

American Academy of Ophthalmology (2013) American Academy of Ophthalmology: http://www.aao.org/pediatric-center-detail/pediatric-cataracts-overview. Retrieved September 16, 2016.

Atkinson J, Braddick O (2013) Inferences about infants' visual brain mechanisms. Vis Neurosci 30(5-6):185-195.

Bangarter A (1959) Orthoptische behandlung des Begleitschielen pleoptik (monokulare orthoptik). XVII Concilium Ophtnafmofogicum 1958, Brussels, Imprimerie Medicale et Scientifique.

Banks MS, Bennett PJ (1988) Optical and photoreceptor immaturities limit the spatial and chromatic vision of human neonates. J Opt Soc Am A 5:2059-2079. CrossRef Medline

Banks MS, Salapatek P (1978) Acuity and contrast sensitivity in 1-, 2-, and 3-month-old human infants. Invest Ophthalmol Vis Sci 17:361-365. Medline

Barlow HB (1972) Single units and sensation: a neuron doctrine for perceptual psychology? Perception 1:371-394. CrossRef Medline

Baroncelli L, Maffei L, Sale A (2011) New perspectives in amblyopia therapy on adults: a critical role for the excitatory/inhibitory balance. Front Cell Neurosci 5:25. CrossRef Medline

Batardière A, Barone P, Knoblauch K, Giroud P, Berland M, Dumas AM, Kennedy H (2002) Early specification of the hierarchical organization of visual cortical areas in the macaque monkey. Cereb Cortex 12:453-465. CrossRef Medline

Bell AH, Pasternak T, Ungerleider LG (2014) Ventral and dorsal processing streams. In: The new visual neurosciences (Werner J, Chalupa L, eds), pp 227-242. Cambridge, MA: Massachusetts Institute of Technology.

Bi H, Zhang B, Tao X, Harwerth RS, Smith EL 3rd, Chino YM (2011) Neuronal responses in visual area V2 (V2) of macaque monkeys with strabismic amblyopia. Cereb Cortex 2:2033-2045. CrossRef Medline

Birch EE, Stager DR (1996) The critical period for surgical treatment of dense congenital unilateral cataract. Invest Ophthalmol Vis Sci 37:1532_ 1538. Medline

Blakemore C, Van Sluyters RC (1974) Reversal of the physiological effects of monocular deprivation in kittens: further evidence for a sensitive period. J Physiol 237:195-216. CrossRef Medline

Blakemore C, Vital-Durand F (1981) Postnatal development of the monkey's visual system. Ciba Found Symp 86:152-171. Medline

Blakemore C, Vital-Durand F (1986a) Organization and post-natal development of the monkey's lateral geniculate nucleus. J Physiol 380:453491. CrossRef Medline

Blakemore C, Vital-Durand F (1986b) Effects of visual deprivation on the development of the monkey's lateral geniculate nucleus. J Physiol 380: 493-511. CrossRef Medline

Blasdel G, Obermayer K, Kiorpes L (1995) Organization of ocular dominance and orientation columns in the striate cortex of neonatal macaque monkeys. Vis Neurosci 12:589-603. CrossRef Medline

Bochner DN, Sapp RW, Adelson JD, Zhang S, Lee H, Djurisic M, Syken J, Dan Y, Shatz CJ (2014) Blocking PirB up-regulates spines and functional synapses to unlock visual cortical plasticity and facilitate recovery from amblyopia. Sci Transl Med 6:258ra140. CrossRef Medline

Boothe RG, Dobson V, Teller DY (1985) Postnatal development of vision in human and nonhuman primates. Annu Rev Neurosci 8:495-545. CrossRef Medline

Boothe RG, Kiorpes L, Williams RA, Teller DY (1988) Operant measurements of contrast sensitivity in infant macaque monkeys during normal development. Vision Res 28:387-396. CrossRef Medline

Braddick O, Atkinson J (2011) Development of human visual function. Vision Res 51:1588-1609. CrossRef Medline

Brown AM, Lindsey DT, Satgunam P, Miracle JA (2007) Critical immaturities limiting infant binocular stereopsis. Invest Ophthalmol Vis Sci 48: 1424-1434. CrossRef Medline

Callaway EM (1998) Prenatal development of layer-specific local cortical circuits in primary visual cortex of the macaque monkey. J Neurosci 18:1505-1527. Medline

Candy TR, Crowell JA, Banks MS (1998) Optical, receptoral, and retinal constraints on foveal and peripheral vision in the human neonate. Vision Res 38:3857-3870. CrossRef Medline

Chino YM, Smith EL 3rd, Hatta S, Cheng H (1997) Postnatal development of binocular disparity sensitivity in neurons of the primate visual cortex. J Neurosci 17:296-307. Medline

Coleman JE, Heynen AJ, Bear MF (2013) The molecular and structural basis of amblyopia. In: The new visual neurosciences (Werner J, Chalupa L, eds), pp 1433-1444. Cambridge, MA: Massachusetts Institute of Technology.

Coogan TA, Van Essen DC (1996) Development of connections within and between areas V1 and V2 of macaque monkeys. J Comp Neurol 372:327342. CrossRef Medline

Crawford ML, de Faber JT, Harwerth RS, Smith EL 3rd, von Noorden GK (1989) The effects of reverse monocular deprivation in monkeys: II. Electrophysiological and anatomical studies. Exp Brain Res 74:338-347. CrossRef Medline

Daw NW (1995) Visual development. New York: Plenum.

Daw NW (1998) Critical periods and amblyopia. Arch Ophthalmol 116: 502-505. CrossRef Medline

De Valois RL, Morgan HC, Polson MC, Mead WR, Hull EM (1974a) Psychophysical studies of monkey vision: I. Macaque luminosity and color vision tests. Vision Res 14:53-67. CrossRef Medline

De Valois RL, Morgan H, Snodderly DM (1974b) Psychophysical studies of monkey vision: III. Spatial luminance contrast sensitivity tests of macaque and human observers. Vision Res 14:75-81. CrossRef Medline

Distler C, Bachevalier J, Kennedy C, Mishkin M, Ungerleider LG (1996) Functional development of the corticocortical pathway for motion analysis in the macaque monkey, a ${ }^{14} \mathrm{C}$-2-deoxyglucose study. Cereb Cortex 6:184-195. CrossRef Medline

Ellemberg D, Lewis TL, Liu CH, Maurer D (1999) Development of spatial and temporal vision during childhood. Vision Res 39:2325-2333. CrossRef Medline

El-Shamayleh Y, Kiorpes L, Kohn A, Movshon JA (2010) Visual motion processing by neurons in area MT of macaque monkeys with experimental amblyopia. J Neurosci 30:12198-12209. CrossRef Medline

Espinosa JS, Stryker MP (2012) Development and plasticity of the primary visual cortex. Neuron 75:230-249. CrossRef Medline

Fantz RL (1958) Pattern vision in young infants. Psychol Rec 8:43-47.

Geisler WS (1984) Physical limits of acuity and hyperacuity. J Opt Soc Am A 1:775-782. CrossRef Medline

Geisler WS (2004) Ideal observer analysis. In: The new visual neurosciences (Werner J, Chalupa L, eds), pp 825-837. Cambridge, MA: Massachusetts Institute of Technology.

Giffin F, Mitchell DE (1978) The rate of recovery of vision after early monocular deprivation in kittens. J Physiol 274:511-537. CrossRef Medline

Goodman CS, Shatz CJ (1993) Developmental mechanisms that generate precise patterns of neuronal connectivity. Cell 2 [Suppl]:77-98.

Hall-Haro C, Kiorpes L (2008) Normal development of pattern motion sensitivity in macaque monkeys. Vis Neurosci 25:675-684. CrossRef Medline

Harwerth RS, Smith EL 3rd, Boltz RL, Crawford ML, von Noorden GK (1983) Behavioral studies on the effect of abnormal early visual experience in monkeys: spatial modulation sensitivity. Vision Res 23:15011510. CrossRef Medline

Harwerth RS, Smith EL 3rd, Crawford ML, von Noorden GK (1989) The effects of reverse monocular deprivation in monkeys: I. Psychophysical experiments. Exp Brain Res 74:327-347. CrossRef Medline

Harwerth RS, Smith EL 3rd, Crawford ML, von Noorden GK (1990) Behavioral studies of the sensitive periods of development of visual functions in monkeys. Behav Brain Res 41:179-198. CrossRef Medline

Hawken MJ, Blakemore C, Morley JW (1997) Development of contrast sensitivity and temporal-frequency selectivity in primate lateral geniculate nucleus. Exp Brain Res 114:86-98. CrossRef Medline

Hendrickson AE, Movshon JA, Eggers HM, Gizzi MS, Boothe RG, Kiorpes L (1987) Effects of early unilateral blur on the macaque's visual system: II. Anatomical observations. J Neurosci 7:1327-1339. Medline

Hensch TK (2004) Critical period regulation. Annu Rev Neurosci 27:549579. CrossRef Medline

Hess EH (1959) Imprinting. Science 130:733. CrossRef Medline 
Horton JC, Hocking DR (1996) An adult-like pattern of ocular dominance columns in striate cortex of newborn monkeys prior to visual experience. J Neurosci 16:1791-1807. Medline

Horton JC, Hocking DR (1997) Timing of the critical period for plasticity of ocular dominance columns in macaque striate cortex. J Neurosci 17: 3684-3709. Medline

Horton JC, Hocking DR, Kiorpes L (1997) Pattern of ocular dominance columns and cytochrome oxidase activity in a macaque monkey with naturally occurring anisometropic amblyopia. Vis Neurosci 14:681-689. CrossRef Medline

Hubel DH, Wiesel TN (1963) Receptive fields of cells in striate cortex of very young, visually inexperienced kittens. J Neurophysiol 26:994-1002. Medline

Hubel DH, Wiesel TN, LeVay S (1977) Plasticity of ocular dominance columns in monkey striate cortex. Philos Trans R Soc Lond B Biol Sci 278: 377-409. CrossRef Medline

Kaas JH (2004) The evolution of the visual system in primates. In: The new visual neurosciences (Werner J, Chalupa L, eds), pp 1563-1572. Cambridge, MA: Massachusetts Institute of Technology.

Katz LC, Crowley JC (2002) Development of cortical circuits: lessons from ocular dominance columns. Nat Rev Neurosci 3:34-42. CrossRef Medline

Kennedy H, Burkhalter A (2004) Ontogenesis of cortical connectivity. In: The new visual neurosciences (Werner J, Chalupa L, eds), pp 146-158. Cambridge, MA: Massachusetts Institute of Technology.

Kiorpes L (1989) The development of spatial resolution and contrast sensitivity in naturally strabismic monkeys. Clin Vis Sci 4:279-293.

Kiorpes L (1992) Development of Vernier acuity and grating acuity in normally reared monkeys. Vis Neurosci 3:243-251. Medline

Kiorpes L (1992b) Effect of strabismus on the development of vernier acuity and grating acuity in monkeys. Vis Neurosci 9:253-259. CrossRef Medline

Kiorpes L (2006) Visual processing in amblyopia: animal studies. Strabismus 14:3-10. CrossRef Medline

Kiorpes L (2008) Macaque models of visual development and disability. In: Nonhuman primate models of children's health and developmental disabilities (Burbacher TM, Sackett GP, Grant KS, eds), pp 45-70. London: Academic.

Kiorpes L (2015) Visual development in primates: neural mechanisms and critical periods. Dev Neurobiol 75:1080-1090. CrossRef Medline

Kiorpes L, Bassin SA (2003) Development of contour integration in macaque monkeys. Vis Neurosci 20:567-575. CrossRef Medline

Kiorpes L, Boothe RG (1980) The time course for the development of strabismic amblyopia in infant monkeys (Macaca nemestrina). Invest Ophthalmol Vis Sci 19:841-845. Medline

Kiorpes L, Mangal P (2015) “Global" visual training and extent of transfer in amblyopic macaque monkeys. J Vis 15:14. CrossRef Medline

Kiorpes L, Movshon JA (2004a) Neural limitations on visual development in primates. In: The new visual neurosciences (Werner J, Chalupa L, eds), pp 159-173. Cambridge, MA: Massachusetts Institute of Technology.

Kiorpes L, Movshon JA (2004b) Development of sensitivity to visual motion in macaque monkeys. Vis Neurosci 21:851-859. CrossRef Medline

Kiorpes L, Movshon JA (2014) Neural limitations on visual development in primates: beyond striate cortex. In: The new visual neurosciences (Werner J, Chalupa L, eds), pp 1423-1431. Cambridge, MA: Massachusetts Institute of Technology.

Kiorpes L, Boothe RG, Hendrickson AE, Movshon JA, Eggers HM, Gizzi MS (1987) Effects of early unilateral blur on the macaque's visual system: I. Behavioral observations. J Neurosci 7:1318-1326. Medline

Kiorpes L, Carlson M, Alfi D (1989) Development of visual acuity in experimentally strabismic monkeys. Clin Vis Sci 4:95-106.

Kiorpes L, Kiper DC, O'Keefe LP, Cavanaugh JR, Movshon JA (1998) Neuronal correlates of amblyopia in the visual cortex of macaque monkeys with experimental strabismus and anisometropia. J Neurosci 18:64116424. Medline

Kiorpes L, Tang C, Hawken MJ, Movshon JA (2003) Ideal observer analysis of the development of spatial contrast sensitivity in macaque monkeys. J Vis 3:630-641. CrossRef Medline

Kiorpes L, Tang C, Movshon JA (2006) Sensitivity to visual motion in amblyopic macaque monkeys. Vis Neurosci 23:247-256. CrossRef Medline

Kiorpes L, Price T, Hall-Haro C, Movshon JA (2012) Development of sen- sitivity to global form and motion in macaque monkeys (Macaca nemestrina). Vis Res 63:34-42. CrossRef Medline

Kiorpes L, Dobkins K, Mendola JD (2013) Linking hypotheses in visual neuroscience. Vis Neurosci 30:183-184. CrossRef Medline

Kiper DC, Kiorpes L (1994) Suprathreshold contrast sensitivity in experimentally strabismic monkeys. Vis Res 34:1575-1583. CrossRef Medline

Kozma P, Kiorpes L (2003) Contour integration in amblyopic monkeys. Vis Neurosci 20:577-588. CrossRef Medline

Lambert SR, Lynn M, Drews-Botsch C, Loupe D, Plager DA, Medow NB, Wilson ME, Buckley EG, Drack AV, Fawcett SL (2001) A comparison of grating visual acuity, strabismus, and reoperation outcomes among children with aphakia and pseudophakia after unilateral cataract surgery during the first six months of life. J AAPOS 5:70-75. CrossRef Medline

Levi DM (2005) Perceptual learning in adults with amblyopia: a reevaluation of critical periods in human vision. Dev Psychobiol 46:222-232. CrossRef Medline

Levi DM (2013) Linking assumptions in amblyopia. Vis Neurosci 30:277287. CrossRef Medline

Levitt JB, Schumer RA, Sherman SM, Spear PD, Movshon JA (2001) Visual response properties of neurons in the LGN of normally reared and visually deprived macaque monkeys. J Neurophysiol 85:2111-2129. Medline

Maruko I, Zhang B, Tao X, Tong J, Smith EL 3rd, Chino YM (2008) Postnatal development of disparity sensitivity in visual area 2 (v2) of macaque monkeys. J Neurophysiol 100:2486-2495. CrossRef Medline

Mayer DL, Dobson V (1982) Visual acuity development in infants and young children, as assessed by operant preferential looking. Vis Res 22: 1141-1151. CrossRef Medline

Mitchell DE (1989) Normal and abnormal visual development in kittens: insights into the mechanisms that underlie visual perceptual development in humans. Can J Psychol 43:141-164. CrossRef Medline

Mitchell DE (1991) The long-term effectiveness of different regimens of occlusion on recovery from early monocular deprivation in kittens. Philos Trans R Soc Lond B Biol Sci 333:51-79. CrossRef Medline

Mitchell DE, Sengpiel F (2009) Neural mechanisms of recovery following early visual deprivation. Philos Trans R Soc Lond B Biol Sci 364:383-398. CrossRef Medline

Movshon JA (1976a) Reversal of the physiological effects of monocular deprivation in the kitten's visual cortex. J Physiol 261:125-174. CrossRef Medline

Movshon JA (1976b) Reversal of the behavioural effects of monocular deprivation in the kitten. J Physiol 261:175-187. CrossRef Medline

Movshon JA, Kiorpes L (1990) The role of experience in visual development. In: Development of sensory systems in mammals (Coleman JR, ed), pp 155-202. New York: Wiley.

Movshon JA, Van Sluyters RC (1981) Visual neural development. Annu Rev Psychol 32:477-522. CrossRef Medline

Movshon JA, Adelson EH, Gizzi MS, Newsome WT (1985) The analysis of moving visual patterns. In: Pattern recognition mechanisms (Chagas C, Gattass R, Gross C, eds). pp 117-125. Rome: Vatican.

Movshon JA, Eggers HM, Gizzi MS, Hendrickson AE, Kiorpes L, Boothe RG (1987) Effects of early unilateral blur on the macaque's visual system: III. Physiological observations. J Neurosci 7:1340-1351. Medline

Movshon JA, Kiorpes L, Hawken MJ, Cavanaugh JR (2005) Functional maturation of the macaque's lateral geniculate nucleus. J Neurosci 25:27122722. CrossRef Medline

Nagakura I, Mellios N, Sur M (2014) Mechanisms of visual cortex plasticity during development. In: The new visual neurosciences (Werner J, Chalupa L, eds), pp 1359-1368. Cambridge, MA: Massachusetts Institute of Technology.

Nakatsuka C, Zhang B, Watanabe I, Zheng J, Bi H, Ganz L, Smith EL, Harwerth RS, Chino YM (2007) Effects of perceptual learning on local stereopsis and neuronal responses of V1 and V2 in prism-reared monkeys. J Neurophysiol 97:2612-2626. CrossRef Medline

Norcia AM, Tyler CW, Hamer RD (1990) Development of contrast sensitivity in the human infant. Vis Res 30:1475-1486. CrossRef Medline

O'Dell C, Boothe RG (1997) The development of stereoacuity in infant rhesus monkeys. Vis Res 37:2675-2684. CrossRef Medline

Packer O, Hendrickson AE, Curcio CA (1990) Development redistribution of photoreceptors across the Macaca nemestrina (pigtail macaque) retina. J Comp Neurol 298:472-493. CrossRef Medline

Pallett PM, Dobkins KR (2013) Development of face discrimination abili- 
ties, and relationship to magnocellular pathway development, between childhood and adulthood. Vis Neurosci 30:251-262. CrossRef Medline

Peterzell DH, Werner JS, Kaplan PS (1995) Individual differences in contrast sensitivity functions: longitudinal study of 4-, 6- and 8-month-old human infants. Vis Res 35:961-979. CrossRef Medline

Rakic P (1977) Prenatal development of the visual system in rhesus monkey. Philos Trans R Soc Lond B Biol Sci 278:245-260. CrossRef Medline

Rodman HR, Scalaidhe SP, Gross CG (1993) Response properties of neurons in temporal cortical visual areas of infant monkeys. J Neurophysiol 70:1115-1136. Medline

Shatz CJ (1990) Impulse activity and the patterning of connections during CNS development. Neuron 5:745-756. CrossRef Medline

Shooner C, Hallum LE, Kumbhani RD, Ziemba CM, Garcia-Marin V, Kelly JG, Majaj NJ, Movshon JA, Kiorpes L (2015) Population representation of visual information in areas V1 and V2 of amblyopic macaques. Vis Res 114:56-67. CrossRef Medline

Smith EL 3rd, Chino YM, Ni J, Cheng H, Crawford ML, Harwerth RS (1997) Residual binocular interactions in the striate cortex of monkeys reared with abnormal binocular vision. J Neurophysiol 78:1353-1362. Medline

Springer AD, Hendrickson AE (2005) Development of the primate area of high acuity: 3. Temporal relationships between pit formation, retinal elongation and cone packing. Vis Neurosci 22:171-185. CrossRef Medline

Stavros KA, Kiorpes L (2008) Behavioral measurement of temporal contrast sensitivity development in macaque monkeys (Macaca nemestrina). Vis Res 48:1335-1344. CrossRef Medline

Teller DY (1984) Linking propositions. Vis Res 24:1233-1246. CrossRef Medline

Teller DY (1997) First glances: the vision of infants, the Friedenwald lecture. Invest Ophthalmol Vis Sci 38:2183-2203. Medline

Teller DY, Boothe R (1979) Development of vision in infant primates. Trans Ophthalmol Soc U K 99:333-337. Medline

Teller DY, Movshon JA (1986) Visual development. Vis Res 26:1483-1506. CrossRef Medline

Van Essen D (2004) Organization of visual areas in macaque and human cerebral cortex. In: The new visual neurosciences (Werner J, Chalupa L, eds), pp 507-521. Cambridge, MA: Massachusetts Institute of Technology.

Von Noorden GK, Dowling JE (1970) Experimental amblyopia in monkeys: II. Behavioral studies in strabismic amblyopia. Arch Ophthalmol 84:215220. CrossRef Medline

Welchman AE, Kourtzi Z (2013) Linking brain imaging signals to visual perception. Vis Neurosci 30:229-241. CrossRef Medline

Wensveen JM, Smith EL 3rd, Hung LF, Harwerth RS (2011) Brief daily periods of unrestricted vision preserve stereopsis in strabismus. Invest Ophthalmol Vis Sci 52:4872-4879. CrossRef Medline

Wiesel TN (1982) Postnatal development of the visual cortex and the influence of environment. Nature 299:583-591. CrossRef Medline

Wiesel TN, Hubel DH (1963) Single-cell responses in striate cortex of kittens deprived of vision in one eye. J Neurophysiol 26:1003-1017. Medline

Wiesel TN, Hubel DH (1974) Ordered arrangement of orientation columns in monkeys lacking visual experience. J Comp Neurol 158:307-318. CrossRef Medline

Yuodelis C, Hendrickson A (1986) A qualitative and quantitative analysis of the human fovea during development. Vis Res 26:847-855. CrossRef Medline

Zhang B, Zheng J, Watanabe I, Maruko I, Bi H, Smith EL 3rd, Chino Y (2005) Delayed maturation of receptive field center/surround mechanisms in V2. Proc Natl Acad Sci U S A 102:5862-5867. CrossRef Medline

Zhang B, Smith EL 3rd, Chino YM (2008) Postnatal development of onset transient responses in macaque V1 AND V2 neurons. J Neurophysiol 100:1476-1487. CrossRef Medline

Zhang B, Tao X, Shen G, Smith EL 3rd, Ohzawa I, Chino YM (2013) Receptive-field subfields of V2 neurons in macaque monkeys are adultlike near birth. J Neurosci 33:2639-2649. CrossRef Medline

Zheng J, Zhang B, Bi H, Maruko I, Watanabe I, Nakatsuka C, Smith EL 3rd, Chino YM (2007) Development of temporal response properties and contrast sensitivity of V1 and V2 neurons in macaque monkeys. J Neurophysiol 97:3905-3916. CrossRef Medline 